\title{
Student Power in Medieval
}

\section{Universities}

V. R. Cardozier

\begin{abstract}
Current student power efforts have precedent in medieval universities, primarily at Bologna, which was a completely student-dominated university. The university government was composed of students only, except for the chancellor, a church appointee whose power was limited largely to awarding degrees. Professors were required to abide by student-approved regulations, to swear obedience to the (student) rector, and to follow procedures prescribed by students in conduct of classes. Either by church or royal decree, students enjoyed privileges unknown today, such as freedom from taxation and military service, often freedom from arrest and trial in civil courts, and other considerations.
\end{abstract}

\begin{abstract}
CURRENT ATTEMPTs by university students to gain more control over their own affairs and over university government in general are not a new phenomenon. Their desire to influence curricula, course content, teaching methods, grading, selection and promotion of professors, to gain student representation on university governing bodies, freedom from police intervention in campus demonstrations, and complete self-determination of non-academic student life, all have precedents in medieval universities.

The most complete student control of universities occurred at Bologna during the 13th and 14th centuries. Most of the student control at other European universities was adopted from Bologna but at no other university did this control equal or even approach that at Bologna.
\end{abstract}

V. R. CARDozien is Visiting Scholar, Center for the Study of Higher Education, University of Michigan, Ann Arbor.

\section{UNIVERSITY GOVERNMENT}

Student power at Bologna evolved naturally from the circumstances under which the university developed. It began as a collection of teachers who practiced essentially as independent entrepreneurs. Although the teachers formed guilds quite early, these were informal and without power.

While almost all of the teachers were Bolognese, most of the students were foreigners. To protect themselves from injustices by the city and to provide other services cooperatively, the students began in the early part of the 13th century to form societies, referred to as "nations," based on their places of origin (Rashdall, 1936). In order to gain public acceptance, these nations were patterned after the trade guilds which shortly before had come into vogue.

Each of the nations elected a councilor who, together, elected the university rector. All councilors and rectors were 
students. The rector was required to be at least 24 years of age, have completed at least five years' study of law, be unmarried and be a secular clerk, i.e., bear that designation from the church.

Students from all of the nations constituted the congregation of the university, which established rules and regulations that applied not only to themselves but also to professors and, indeed, to the servants, landlords, and others who did business with the students. Professors, who were not permitted to be members of the congregation nor to vote, opposed the growth of student power but were unable to check it. In time, the faculty came to be dominated almost completely by the students.

While Bologna was a student-controlled university, the university of Paris was a university of masters. At Paris both teachers and students were non-Parisian, thus the masters had need for a guild to protect them from the citizens. In addition, students at Paris were much younger-usually between 13 and 16 when they enteredthan those at Bologna, who were often well past 20 when they entered and, due to a longer period of study, were frequently near 30 when they completed their studies.

The masters at Paris were quite young, many of them about the same age as the students at Bologna. In fact, many of the teachers at Paris were students in the superior faculties-law, medicine, and theology-while serving as masters in the arts university. Thus it was the masters' guilds that constituted the congregation and the governing body of the university.

The university at Montpellier was organized much like that at Paris, but the role of students tended to be like that at Bologna. Initially, the university government included two proctors selected by the masters and one chosen by the students. Later, there were also two councilors, one of whom was a student and the other a bachelor (in today's term, a graduate student). Although the masters at Montpellier substantially had complete control in the beginning, students increasingly demanded privileges enjoyed by students at Bologna, and by 1340 any statute affecting students required their consent as well. Students participated in selecting courses to be offered, through an annual meeting of all faculty and students.

At Toulouse, in the early 14th century, we find that the rector must be a master, but he was elected by the students. Students also enacted university rules but had little influence upon their administration. Student rioting at Angers and Orleans during the last half of the 14th century led to increased student representation in university government. But at Avignon, where church influence was strong, riots and rebellion had little effect during the 14th century. In 1459, however, students prevailed on Pope Pius II to support them, which led to their gaining two student seats on the university's ruling council.

At Prague, students who were elected proctors of their nations sat with the faculty on the university council. The law students insisted on privileges comparable to those at Bologna and were permitted to withdraw and form a university of their own.

At Salamanca, the Bologna pattern was adopted (Kibre, 1948). The rector was a student, elected annually, who was assisted by eight student councilors elected by the nations. Unlike at Bologna, however, the professors had a strong guild with a prior elected by themselves. Nevertheless, all doctors, masters, licentiates, bachelors, and students were obliged to take an oath of obedience to the student rector.

In German universities, students never commanded quite the same power found in universities of other countries. Rather early in the development of the German university the power of the nations was transferred to a university council, which was composed of teachers. Later, about the only semblance of student power left was the student right to elect the rector.

Lack of student power in German uni. versities was due in large measure to the fact that from the beginning professors were endowed rather than having to rely on fees, and unlike Paris and Bologna, where professors were identified with a college or nation, German professors were university teachers.

When the University of St. Andrews was founded in 1411, nations were established which included both students and 
faculty, all of whom participated in the election of the rector. The Bishop of Glasgow served as chancellor of the university in that city but delegated his functions to a student-elected rector. At Aberdeen, there were four nations of students, each of which elected a proctor who together selected the rector.

\section{ACADEMIC INFLUENCE}

Although student power prevailed at all medieval universities in varying degrees, nowhere did student influence on the curriculum, course content, teaching, and professors' behavior resemble that at Bologna. This power was based on the fee-paying system. Each student negotiated directly with his professor concerning fees. Any professor who failed to comply with the rules and regulations passed by the congregation was boycotted, thereby terminating his income.

In the early organization of nations, little attempt was made by students at Bologna to control academic matters. But as their power grew, students came to have virtually absolute control over professors and their teaching.

The university statutes regulating professors' teaching were detailed and lengthy. The first required that professors take an oath of obedience to the (student) rector and to abide by all regulations that might be imposed on them. Professors were forbidden to be absent from classes, even for a single day, without good excuse and then only after approval by the class, the councilor, and the rector. Students were pledged by oath to report any professor who was absent without permission. If the professor failed to attract at least five students to a given lecture, he was considered absent himself and fined.

Student statutes also required that the professor start his lecture at the beginning of the book, cover each section sequentially, and complete the book by the end of the term. He was not permitted to skip a difficult portion, with a view to returning to it at the end of the term, lest it be overlooked entirely.

In a later period the professor was required to complete each section of the book according to a predetermined schedule. If he failed to achieve the schedule he was fined from a sum which he had deposited at the beginning of the term with a local banker. To assure absolute surveillance, a committee of students was appointed to observe each professor and to report any violations of statutes to the rector.

\section{TOWN AND GOWN}

Both students and faculty enjoyed a number of privileges from the state in the Middle Ages. Most of them were not new. From pre-Christian Greece, teachers and students had been free from taxation, free from military service, and in many places free from arrest and trial by civil authorities (Norton, 1909).

But these privileges did not automatically come to students and faculty. It was because they did not enjoy the same protection as citizens of Bologna that the foreign students organized themselves into nations. When they gained power, the students were almost insatiable in their demands.

The townspeople were cowed by the students and the professors, both of whom used the migration as a threat to force compliance with their wishes. Threats by students and faculty to move to another city were by no means hollow. Migrations were quite common during the Middle Ages. Most of the major universities of Europe were begun or developed by professors and students who had become unhappy at Bologna or Paris. Such migrations were simple affairs since there were no university buildings, libraries, or equipment to limit mobility. Classes were held in professors' homes, in churches, rented halls, and assorted other buildings.

Students gained many concessions from the city of Bologna. Foremost was the granting to the university (student) rector authority over law violations by students, including criminal acts in which both principals were students. In 1432, students could be arrested only with permission of the rector (Kibre, 1962).

Student control permeated the entire city. University officials inspected each house for rental to students and set the rental rate. If the landlord exceeded this rate the house was boycotted by students for five years. Rates and services of trades- 
men were also monitored and transgressions were punished by withholding student business. A university-appointed committee of four student officials examined and approved money lenders and regulated the rates of interest that could be charged students for money borrowed.

The many demands and harsh sanctions placed upon the city and its people resulted in almost continuous conflict between the students and the citizens of Bologna.

At Paris there were difficulties between students and the citizens throughout most of the Middle Ages. Frequently the young masters of arts were involved alongside the students; this gave the latter more power in their threats to migrate. Most reported incidents of "town and gown" trouble at Paris and Oxford began in taverns.

In 1200 a battle in a tavern at Paris resulted in several students being slain by police. The king, fearing the students would migrate, condemned the police and ordered the burning of the homes of the citizens who had fought the students. He also decreed that in the future police must hand students over to the church for punishment, and required that Parisians take an oath not to harm students and to report anyone seen harming a student.

The best known battle of students and townspeople at Paris occurred in 1229. A group of students, drinking at a suburban tavern, assaulted the tavern keeper. He called for assistance and with the help of neighbors retaliated by beating the students severely. The following day the students returned with reinforcements and virtually destroyed the tavern. When the police went to a playing field to arrest the students, a battle ensued in which several students were killed. This brought about serious conflict between town and gown and was the basis of several migrations of students and teachers-to Oxford, Orleans, Toulouse, and others.

Again, because of student and faculty threats, King Philip issued a proclamation in 1306 stating that all university teachers and students at Paris were under special guardianship and should be free from annoyances, injury, oppression, and violence by citizens. Students and faculty were also privileged not to be moved from Paris to testify at trials; the trials had to be moved to Paris if they were to testify.

At Vienna, students enjoyed many privileges. If accused of capital crimes, they were tried before the chancellor of the university, rather than before civil authorities, and for lesser offenses, before the rector. The students were also privileged to demand lodgings of their choice in a particular section of the city and at rates set by arbitration. Although students at Vienna had more privileges than those at Paris, Vienna was nonetheless a university of masters.

At Oxford, difficulties between town and gown were similar to those at Paris. The citizens were frequently abused by students and found little comfort in either the church or crown in seeking relief. In 1355 the people of the town of Oxford killed several students of the university in a brawl that started in a tavern. The king not only punished the offenders, but established a law virtually subjecting the town to the rule of university officials. The chancellor was given jurisdiction over private citizens in any case where one of the principals was a student.

\section{IN LOCO PARENTIS}

The principle of in loco parentis was almost unknown in the early Middle Ages. In German universities, then as now, students were expected to arrange their own lodgings and to be completely responsible for their own activities and behavior.

A secondary purpose of the nations organized at Bologna was to make it possible for students to acquire houses for lodging and to operate them as cooperatives. Such arrangements were solely the responsibility of the students. The fact that they were older than students elsewhere was undoubtedly a factor in the kind of independence they enjoyed.

At Paris, students had to shift for themselves in the beginning. Later, to make it possible for poor students to study at the university, charitable organizations and persons purchased and endowed houses for them. These were known as hospices and later as colleges. Initially the students operated the hospices themselves but soon a master of arts was placed in each house, which led to increased control 
over students' hours, behavior, and activities.

At Oxford and Cambridge, students tended to be quite young, like those at Paris. They were very likely to be little if any older when they received the B.A. than today's high school seniors. In the early years of Oxbridge, students enjoyed considerable freedom. Student residence halls were presided over by a principal, elected from their numbers. The arriving student customarily took lodging for a night or two at a local inn while deciding which residence hall and master to choose. Often emissaries visited him to recruit him for a master.

Until the beginning of the 15th century, Oxbridge students were relatively free from university restrictions. During that century, however, marked changes occurred, and at the end of it the pattern was virtually reversed. Masters came to serve as principals of the residence halls, students were required to be in their lodgings by an early hour in the evening, and by the turn of the century floggings were not uncommon. From that time, stringent rules were instituted and governed the lives of Oxbridge students for the centuries to come.

\section{LOSS OF POWER}

Students at Bologna were unwittingly a party to the tempering of their own power. The extremes of student control became increasingly irritating to professors, especially the unpleasant task of negotiating and collecting fees. It was not uncommon to find a famous professor engaged in undignified bargaining with a student about fees. Professors appealed to the city of Bologna to provide endowed chairs. The first two chairs were established in 1230, and since the students were to select the two professors to fill the chairs each year, the students eagerly assisted in appeals for additional chairs. The idea of salaried professors continued to develop and by 1381 there were 23 chairs in the university underwritten by the city.

As the number of chairs and the city's financial contributions increased, gradually the city came to have more influence on the university. A board of governors, composed of citizens, was established which assumed responsibility for the selection of professors to fill the chairs. This led to replacement of the autonomy of the nations by university authority. Student power was on the wane, even though the post of rector continued to be filled by an elected student up to 1796 when Napoleon's troops captured Bologna and dispersed the university. When the university was reformed in 1798 , the position of rector was filled by a professor.

We have seen how the institutionalizing of lodging with faculty supervision laid the foundation for the concept of in loco parentis at Oxford and to a lesser extent at Paris. By the beginning of the 16th century a pattern of student life and faculty control had been established at Oxford and Cambridge that was to prevail for the centuries to come. These institutions served as models for the colleges established in the American colonies during the 17th and 18th centuries. It was, therefore, inevitable that the English pattern, coupled with a strong Puritan ethic, would foster a high degree of faculty control in American colleges up to and including part of the 20th century.

\section{REFERENCES}

Krape, P. The nations in the mediaeval universities. Cambridge, Mass.: Mediaeval Academy of America, 1948.

KIBre, P. Scholarly privileges in the Middle Ages. Cambridge, Mass.: Mediaeval Academy of America, 1962.

Norton, A. O. Readings in the history of education: mediaeval universities. Cambridge, Mass.: Harvard University Press, 1909.

Rasmoatl, H. Universities of Europe in the Middle Ages. (2nd ed.) New York: Oxford University Press, 1936. 